\title{
Characteristics of Mandibular Movement and Mastication in Older Adults with Removable Dental Prostheses: Three-Dimensional Analysis
}

\author{
Características de Movimientos Mandibulares y Masticación en Adultos \\ Mayores con Prótesis Dental Removible: un Análisis Tridimensional
}

\author{
Paloma Rivera1; Constanza Farfán ${ }^{1,2}$; Alain Arias 2, 3, 4; María Florencia Lezcano ${ }^{2,3}$; \\ Fernando José Dias ${ }^{2,3}$; Pablo Navarro ${ }^{2,3,5}$ \& Ramón Fuentes ${ }^{2,3}$
}

\begin{abstract}
RIVERA, P.; FARFÁN, C.; ARIAS, A.; LEZCANO, M. F.; DIAS, F. J.; NAVARRO, P. \& FUENTES, R. Characteristics of mandibular movement and mastication in older adults with removable dental prostheses: Three-dimensional analysis. Int. J. Odontostomat., 14(1):81-88, 2020.

ABSTRACT: Aging is a dynamic process that includes various alterations in the oral cavity, with tooth loss being the most frequent. Rehabilitative treatment may include removable or fixed prostheses and implants. The aim of this study was to describe the geometric (trajectory, ranges, areas) and kinematic (speed) characteristics of the mandibular and masticatory movements threedimensionally in participants with dental prostheses. A sample of 10 participants with removable prosthetic rehabilitation was divided into three groups (complete, atypical and overdenture) the characteristics of mandibular movements bordering and chewing with 3D Electromagnetic Articulography were measured. The Posselt polygonin was obtained, the frontal and sagittal plans, its areas, trajectories and ranges are analyzed. The masticatory movements were analyzed in the area of each cycle, the frequency, the speed and the reason between the masticatory cycle and the bordering movements, no significant differences between the groups. Subjects with dental prostheses, regardless of the type, they showed low of motion (border and functional) compared to dentate subjects with no functional alterations whose values have been reported in the literature. The subjects with overdenture have values closer to what is described for young dentate subjects.
\end{abstract}

KEY WORDS: Mandibular movements, 3D electromagnetic, articulography, removable dental prostheses, older adults

\section{INTRODUCTION}

Aging is a dynamic process, where morphological, biochemical, functional and psychological changes occur (Saez Carriera et al., 2007). The changes in the oral cavity can be related, among other causes, to diseases of the tissues that support the teeth and to decay, with tooth loss being the most frequent result. Tooth loss can alter the esthetic, phonetic and masticatory function, in addition to producing multiple alterations to the homeostasis of the stomatognathic system (Saez Carriera; Matus López 2006; San Martín et al., 2002). Thus, the difficulty in chewing and swallowing results in a perception of reduced quality of life (Saez Carriera et al.; McKenna \& Burke 2010; Budtz-Jørgensen, 1999), which is exacerbated in older adults.
In terms of rehabilitation treatment for people with tooth loss, it has been described that, due to various factors, removable prostheses, complete or partial, can present horizontal and/or vertical movements during function, which causes unilateral mastication with an oscillating motion that impairs prosthetic retention, affects the stability of the occlusal contacts and, therefore, modifies the chewing process (Rosado De Oliveira et al., 2005). A study conducted with kinesiography compared the duration of the masticatory cycles in partially dentate patients rehabilitated with removable and implant-supported prostheses, and the conclusion was that the time of each cycle was significantly shorter in patients with removable partial prostheses (Gonçalves et al., 2014). The chewing action of implant-supported

\footnotetext{
${ }^{1}$ Master Program in Dentistry, Dental School, Universidad de La Frontera, Temuco, Chile.

${ }^{2}$ Research Centre for Dental Sciences (CICO), Dental School, Universidad de La Frontera, Temuco, Chile.

${ }^{3}$ Department of Integral Adults Dentistry, Dental School, Universidad de La Frontera, Temuco, Chile.

${ }^{4}$ Universidad Adventista de Chile, Chillán, Chile.

${ }^{5}$ Universidad Autónoma de Chile, Chile.
} 
RIVERA, P.; FARFÁN, C.; ARIAS, A.; LEZCANO, M. F.; DIAS, F. J.; NAVARRO, P. \& FUENTES, R. Characteristics of mandibular movement and mastication in older adults with removable dental prostheses: Three-dimensional analysis. Int. J. Odontostomat., 14(1):81-88, 2020.

patients with a prosthesis has mainly been studied using electromyography. Some authors have shown that in these patients there is no significant change in the coordination of the masticatory muscles; however, these present a unique chewing pattern because they activate the muscles on the working and balancing sides simultaneously (Gartner et al., 2000).

The mandibular movements (MM) can be classified as margin and functional (Okeson et al., 2008). The former were described by Posselt in 1958 and are determined by the joint anatomy and its ligaments (Okeson et al.; Posselt, 1958). The latter, meanwhile, correspond to the chewing process, defined as a complex function that depends on the coordination of the various muscles of the head and neck, with the participation of a specialized neurological control designed to regulate and coordinate the activities of the entire masticatory system (Okeson et al.). A wide variety of methods has been used to study these movements, most of which are two-dimensional recording systems (Yamashita \& Hatch, 1999; Yoshida et al., 2007; Bourdiol \& Mishellany 2014; Fulks et al., 2017), which supposes a major constraint when analyzing complex processes that occur in three dimensions. In the interest of solving this limitation, technologies classically used in areas such as the study of speech have been applied to the study of MM. Thus, three-dimensional (3D) electromagnetic articulography (EMA) has been positioned as a useful tool for the thorough study of these movements, as it is characterized as having a minimum range of error and being comfortable for the participants (Fuentes et al., 2015, 2017a). Recently, 3D EMA was used to describe border and masticatory movements in young participants with normal occlusion, providing quantitative data regarding the area where the movements occur, their trajectory and the speed of the mandible (Fuentes et al., 2017b). These data allow us to delve more deeply into the classic description of MM in the literature, leading to a new and better understanding of chewing patterns. This same purpose could be applied to the study of MM in other oral conditions and to a better understanding of the change produced by tooth loss and oral rehabilitation. Accordingly, the aim of this study was to describe threedimensionally the geometric (trajectory and areas) and kinematic (speed) characteristics of border and masticatory MM in participants with different types of prosthetic rehabilitation. The comparison between participants with different types of dental prostheses will allow us to enhance understanding of how masticatory function is affected when teeth are gradually lost and when these are rehabilitated.

\section{MATERIAL AND METHOD}

A descriptive study was has been conducted in full accordance with the World Medical Association Declaration of Helsinki. Conducted with approval from the Scientific Ethics Committee of Universidad de La Frontera (Protocol No 038/2016). The geometric and kinematic characteristics of the border and masticatory MM were described using the AG501 3D EMA (Carstens Medizinelektronik, Bovenden, Germany) on a sample of ten adults with removable dental prostheses and implant-supported overdentures who signed the respective informed consent. The participants were distributed as follows: Group 1: two subjects with an average age of $53 \pm 24.71$ years, with complete upper and lower removable prostheses (CRP); Group 2: four subjects with an average age of $64 \pm 12.28$ years, with complete upper and partial lower removable prostheses (CRP-P); and Group 3: four subjects with an average age of $72 \pm 9.12$ years, with complete upper prostheses and mandibular overdenture with two implants (CRP-I). All the participants were treated at the University Dental Clinic by students in their last year of the dentistry program specializing in Oral Rehabilitation at the Universidad de La Frontera. Each of the participants was contacted and invited to participate in this study 6 months after being discharged from dental treatment. It was confirmed that each participant had prosthetic and phonetic stability, and presented no signs or symptoms of temporomandibular disorders (ruled out by applying a clinical examination and self-reporting test recommended by the American Academy of Orofacial Pain) (McNeill, 1993).

Preparation of the participant. The previously reported recording protocol for MM and mastication designed by our research group was used (Fuentes et al., 2018). For the recording with the EMA 3D AG501, 4 sensors were used at specific points on the participant's head and fixed to the skin with a biocompatible tissue adhesive (Epiglu $₫$, EuroKlee S.L., Barcelona, Spain). The sensors were fixed to the: right mastoid (1st), left mastoid (2nd), glabella (3th) and mandibular interincisal midline (4th). The first 3 sensors were used as a reference system to standardize the spatial coordinates of the mandibular sensor that records the movement (Fuentes et al., 2017a, b; 2018).

Recording of the movements and data processing. Once the sensors were placed, the participants were 
RIVERA, P.; FARFÁN, C.; ARIAS, A.; LEZCANO, M. F.; DIAS, F. J.; NAVARRO, P. \& FUENTES, R. Characteristics of mandibular movement and mastication in older adults with removable dental prostheses: Three-dimensional analysis. Int. J. Odontostomat., 14(1):81-88, 2020.

seated in a comfortable position, with an upright posture and facing front under the transmitter coils of the articulograph. Prior to instruction and testing, each participant was asked to perform a series of movements with their jaw. The set of movements is described (Fuentes et al., 2018), and make up the socalled Posselt's envelope of motion in the frontal and sagittal plane. This series of movements was performed three times while being recorded with the articulograph. Then, each participant was asked to chew and completely swallow $3.7 \mathrm{~g}$ of peanuts (Gonçalves et al.,) while the movement was also recorded with the articulograph.

From the records obtained with the 3D EMA, it was possible to collect quantitative data of the movement by processing them with calculation routines using the Matlab software (The MathWorks Inc., USA) (Fuentes et al., 2017b). Thus, it was possible to calculate the opening trajectory $(\mathrm{mm})$, areas of Posselt's envelope of motion in the frontal and sagittal plane $\left(\mathrm{mm}^{2}\right)$, number of masticatory cycles, average area of the masticatory cycles in the frontal and sagittal plane $\left(\mathrm{mm}^{2}\right)$, ratio between the area of the masticatory cycles and the area of the border movement, average frequency of the masticatory cycles (cycles/s) and average mandibular opening and closing speed during mastication $(\mathrm{mm} / \mathrm{s})$.

Statistical analysis. For the statistical analysis, SPSS 23.0 (IBM) was used. The Shapiro-Wilk test was applied to determine the normality of the data. The data with normal distribution were presented with the mean \pm standard deviation, and a one-way ANOVA was applied to analyze differences between the groups, followed by the Bonferroni post hoc test. A value of $p<0.05$ was used as the threshold for significance.

\section{RESULTS}

\section{Opening trajectory}

The average mandibular opening trajectory for the group with CRP $(n=2)$ was $52.56 \pm 8.22 \mathrm{~mm}$, for the group with CRP-P $(n=4) 57.96 \pm 12.23 \mathrm{~mm}$ and for the group with CRP-I $(n=4) 65.69 \pm 4.41 \mathrm{~mm}$ (Table I). No significant differences were found between the groups $(p=0.075)$.

Area of Posselt's envelope of motion in the frontal and sagittal plane. The average area of the polygon of Posselt's envelope of motion in the frontal plane for the group with CRP $(n=2)$ (Fig. 1 A) was $155.88 \pm$ $112.46 \mathrm{~mm}^{2}$, for the group with CRP-P $(\mathrm{n}=4)$ (Fig. $\left.1 \mathrm{~B}\right)$ $221.09 \pm 163.75 \mathrm{~mm}^{2}$, and for the group with CRP-I $(n=4)$ (Fig. 1 C) $318.27 \pm 68.82 \mathrm{~mm}^{2}$. There were no significant differences between the groups $(p=0.208)$. The average area of Posselt's envelope of motion in the sagittal plane (Fig. 2) for the group with CRP $(n=2)$ (Fig. 2 A) was $158.62 \pm 68.43 \mathrm{~mm}^{2}$, for the group with CRP-P ( $\mathrm{n}=4$ (Fig. 2B) $96.43 \pm 40.64 \mathrm{~mm}^{2}$, and for the group with CRP-I ( $\mathrm{n}=4)$ (Fig. 2C) $132.27 \pm 81.57 \mathrm{~mm}^{2}$ (Table II). There were no significant differences between the groups $(p=0.161)$.

Number of masticatory cycles. The average number of masticatory cycles performed to crush $3.7 \mathrm{~g}$ of peanuts for the group with CRP $(n=2)$ was $78.50 \pm 16.26$, for the group with CRP-P $(n=3) 69 \pm 37.16$, and for the group with CRP-I $(n=4) 72.25 \pm 32.09$. There were no significant differences between the groups $(p=0.948)$. The data of one of the participants in the group with CRP-P were excluded from the analysis due to difficulties for the correct mastication and crushing of the food.

Table I. Border mandibular movement and chewing.

\begin{tabular}{|c|c|c|c|c|c|c|c|}
\hline \multirow{4}{*}{$\begin{array}{c}\begin{array}{c}\text { Type of } \\
\text { rehabilitation }\end{array} \\
\text { CRP }\end{array}$} & \multirow{3}{*}{$\begin{array}{c}\text { Subject } \\
1 \\
1\end{array}$} & \multicolumn{2}{|c|}{$\begin{array}{l}\text { Polygon area } \\
\qquad\left(\mathrm{mm}^{2}\right)\end{array}$} & \multicolumn{2}{|c|}{$\begin{array}{l}\text { Masticatory area } \\
\qquad\left(\mathrm{mm}^{2}\right)\end{array}$} & \multicolumn{2}{|c|}{$\begin{array}{c}\text { Ratio } \\
\text { (Polygon area/ } \\
\text { Chewing area) }\end{array}$} \\
\hline & & Frontal & Sagittal & Frontal & Sagittal & Frontal & Sagittal \\
\hline & & 76.36 & 207.01 & 42.10 & 6.78 & 0.55 & 0.03 \\
\hline & 2 & 235.41 & 110.23 & 36.34 & 15.02 & 0.15 & 0.14 \\
\hline \multirow{4}{*}{ CRP-P } & 1 & 325.08 & 142.56 & 15.38 & 10.59 & 0.05 & 0.07 \\
\hline & 2 & 395.66 & 111.64 & 29.35 & 9.53 & 0.07 & 0.09 \\
\hline & 3 & 95.23 & 46.86 & 15.23 & 9.71 & 0.16 & 0.21 \\
\hline & 4 & 68.39 & 84.66 & --- & --- & --- & --- \\
\hline \multirow{4}{*}{ CRP-I } & 1 & 224.86 & 238.59 & 21.89 & 8.87 & 0.1 & 0.04 \\
\hline & 2 & 390.45 & 153.81 & 38.56 & 10.82 & 0.1 & 0.07 \\
\hline & 3 & 333.82 & 64.95 & 23.85 & 9.04 & 0.07 & 0.14 \\
\hline & 4 & 323.94 & 71.73 & 21.14 & 6.73 & 0.07 & 0.09 \\
\hline
\end{tabular}




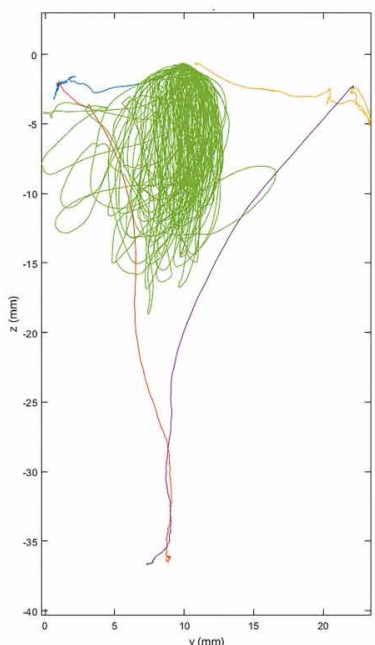

A

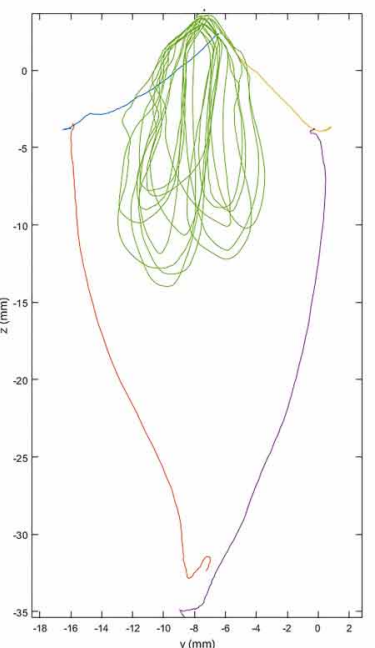

B

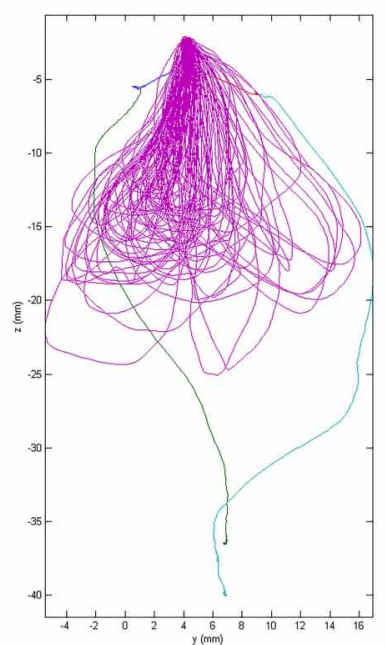

C
Fig. 1. Posselt's envelope of motion frontal with masticatory cycles included: A) Posselt's envelope of motion of participant with CRP; B) Posselt's envelope of motion of participant with CRP$\mathrm{P} ; \mathrm{C})$ Posselt's envelope of motion of participant with CRP-I.
Average area of the masticatory cycles in the frontal and sagittal plane. The average area of the masticatory cycles analyzed in the frontal plane and performed by the participants in the group with CRP $(n=2)$ was $39.22 \pm 4.07 \mathrm{~mm}^{2}$, in the group with CRP-P $(n=3) 19.99 \pm 8.11 \mathrm{~mm}^{2}$ and in the group with CRP-I $(n=4) 26.36 \pm 8.21 \mathrm{~mm}^{2}$. There were no significant differences between the groups $(p=0.085)$. Meanwhile, the area average of the masticatory cycles analyzed in the sagittal plane and performed by the participants in the group with CRP $(n=2)$ was $10.90 \pm 5.82 \mathrm{~mm}^{2}$, in the group with CRP-P $(n=3) 9.94 \pm 0.56 \mathrm{~mm}^{2}$ and in the group with CRP-I $(n=4) 8.87 \pm 1.67 \mathrm{~mm}^{2}$ (Table II). There were no significant differences between the groups $(p=0.682)$.
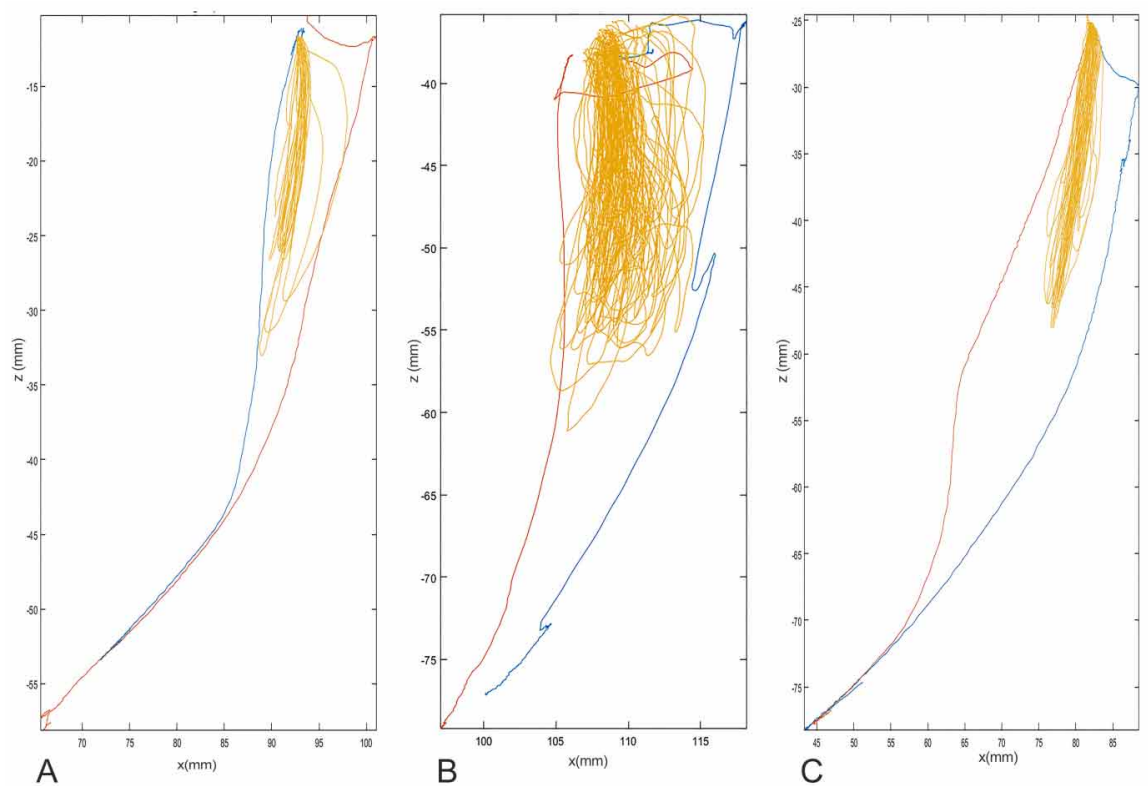

Fig. 2. Posselt's envelope of motion sagittal with masticatory cycles included: A) Posselt's envelope of motion of participant with CRP; B) Posselt's envelope of motion of participant with CRP$\mathrm{P} ; \mathrm{C})$ Posselt's envelope of motion of participant with CRP-I. 
RIVERA, P.; FARFÁN, C.; ARIAS, A.; LEZCANO, M. F.; DIAS, F. J.; NAVARRO, P. \& FUENTES, R. Characteristics of mandibular movement and mastication in older adults with removable dental prostheses: Three-dimensional analysis. Int. J. Odontostomat., 14(1):81-88, 2020.

Table II. Kinematic characteristics of chewing.

\begin{tabular}{cccccc}
\hline $\begin{array}{c}\text { Type of } \\
\text { rehabilitation }\end{array}$ & Subject & $\begin{array}{c}\text { Trajectory } \\
(\mathrm{mm})\end{array}$ & $\begin{array}{c}\text { Frequency } \\
\text { (cycles } / \mathrm{s})\end{array}$ & Ascent & Descent \\
\hline \multirow{2}{*}{ CRP } & 1 & 45.64 & 1.67 & 63.36 & 66.92 \\
& 2 & 59.48 & 1.72 & 55.24 & 68.80 \\
CRP-P & 1 & 62.93 & 1.25 & 37.88 & 48.13 \\
& 2 & 63.56 & 1.17 & 34.54 & 40.98 \\
& 3 & 61.96 & 1.38 & 78.28 & 81.80 \\
& 4 & 43.38 & --- & --- & -- \\
CRP-I & 1 & 64.71 & 1.72 & 51.53 & 45.74 \\
& 2 & 65.57 & 1.39 & 55.24 & 53.14 \\
& 3 & 66.14 & 1.67 & 67.13 & 72.30 \\
& 4 & 66.35 & 0.93 & 31.28 & 34.43 \\
\hline
\end{tabular}

Frequency of the masticatory cycles. The average mastication frequency (cycles per second) for the group with $\operatorname{CRP}(n=2)$ was $1.70 \pm 0.04$ cycles/s, for the group with CRP-P $(n=3) 1.27 \pm 0.11$ cycles/s and for the group with CRP-I $(n=4) 1.43 \pm 0.36$ cycles/s (Table I). There were no significant differences between the groups $(p=0.280)$.

\section{Mandibular opening and closing speed during} mastication. The average speed of mandibular opening during mastication for the participants in the group with CRP $(n=2)$ was $67.86 \pm 14.08 \mathrm{~mm} / \mathrm{s}$, for the group with CRP-P $(n=3) 56.97 \pm 21.18 \mathrm{~mm} / \mathrm{s}$ and for the group with CRP-I $(n=4) 51.40 \pm 16.38 \mathrm{~mm} / \mathrm{s}$. There were statistical differences between all the groups $(P=$ $<0.05)$. Meanwhile, the average speed of mandibular closing during mastication for the participants in the group with CRP $(n=2)$ was $59.30 \pm 12.60 \mathrm{~mm} / \mathrm{s}$, in the group with CRP-P $(n=3) 50.23 \pm 23.37 \mathrm{~mm} / \mathrm{s}$ and in the group with CRP-I $(n=4) 52.05 \pm 15.10 \mathrm{~mm} / \mathrm{s}$ (Table II). There were significant differences between the groups with CRP and CRP-I $(P=<0.001)$. In the ratio between ascent and descent between each group, a statistically significant difference was only found in the groups with $C R P(P=<0.001)$ and CRP-P $(P=<0.001)$.

\section{DISCUSSION}

Previous studies have shown that partially edentulous subjects maintain the presence of periodontal mechanoreceptors in the remaining teeth, related to the transmission of tactile and pressure sensitivity (Guyton \& Hall, 1997; Trulsson, 2006). By contrast, completely edentulous subjects have lost the sensitivity of the periodontal mechanoreceptors entirely; nevertheless, they maintain the mucosal mechanoreceptors in the gingival and palatal mucosa. In those subjects with (complete or partial) removable prostheses, coverage of the mucosa causes a series of functional disturbances that give rise to altered movement patterns during mastication. In spite of this, few studies refer to these alterations or to the effect of prosthetic treatments on masticatory function (Gonçalves et al.; Kodaira et al., 2006; Tallgren et al., 1989; Jemt et al., 1983a). In our study, these movements are characterized in relation to the type of rehabilitative treatment.

As a result of the border MM, Posselt's envelope of motion was obtained in the frontal and sagittal plane for the three groups with prosthetic rehabilitation. In the analysis of the average areas of the polygons, we emphasize that in the frontal plane this value fluctuated between $236.14 \mathrm{~mm}^{2}$ and $302.27 \mathrm{~mm}^{2}$, whereas in a previous study conducted with young subjects (aged between 18 and 22 years) dentate with a class I normal occlusion (Fuentes et al., 2017b), the area of Posselt's envelope of motion in the frontal plane varied between $391.44 \mathrm{~mm}^{2}$ and $566.67 \mathrm{~mm}^{2}$. This indicates a clear reduction in the extreme movements in those subjects with prosthetic rehabilitation, which is accentuated in the group with CRP, whereas in the group with CRP-I the values closest to the values described in dentate subjects with normal occlusion were obtained. This pattern is also repeated for the sagittal plane, where the group with CRP-I recorded the largest areas of movement. This reduction in the range of motion may be due to the aging of the joint in 
RIVERA, P.; FARFÁN, C.; ARIAS, A.; LEZCANO, M. F.; DIAS, F. J.; NAVARRO, P. \& FUENTES, R. Characteristics of mandibular movement and mastication in older adults with removable dental prostheses: Three-dimensional analysis. Int. J. Odontostomat., 14(1):81-88, 2020.

geriatric patients, where the articular disc tends to perforate with age, which is why proprioceptive activity decreases and affects the control of movements (Díaz et al., 2012). On the other hand, the proximity of the values of the subjects with CRP-I to the values of dentate subjects with normal occlusion can be explained by the better prosthetic retention, support and stability in this group, reflected in a better performance of the mandibular movements (Lauzardo et al., 2013). An in vivo study demonstrated that implant-supported subjects with removable partial prostheses have greater force and a larger contact area, offering increased comfort and improving the chewing process compared to conventional prostheses (Holm \& Gotfredsen, 2002; Ohkubo et al., 2008).

Lepley et al. (2011), study conducted an study with the Optotrak $3020 \mathrm{H}$ (Northern Digital, Waterloo, Ontario, Canada), determined the masticatory kinematics in participants with class I and defined between 30 and 35 masticatory cycles as being the required number to swallow. A study recently performed by our team using an EMA established that the number of masticatory cycles for young people with class I normal occlusion was between 9 and 24 cycles (Fuentes et al., 2017b). According to our results, a subject with CRP performs between 67 and 90 cycles for a correct crushing of $3.7 \mathrm{~g}$ of peanuts, in the group with CRP-P it was between 30 and 104 and for the group with CRP-I it was between 42 and 114 . These results are consistent with what has been reported in the literature, where it is indicated that subjects with dental prostheses perform an increased number of masticatory cycles because they have reduced or null peripheral sensitivity due to the loss of the periodontal mechanoreceptors. Consequently, these patients generally develop strategies to overcome the difficulties when chewing by choosing foods that are softer and easier to crush, which is very common in subjects with complete prostheses (Slagter et al., 1993; Woda et al., 2006; N'Gom \& Woda, 2002). Hence, it is not uncommon to find that one of the study participants has had difficulties chewing the $3.7 \mathrm{~g}$ of peanuts as requested.

In order to analyze the chewing process in subjects with a prosthesis, the mastication area in the frontal and sagittal plane was described for the three groups. In the frontal plane, the smallest area recorded was in the group with CRP-P with $19.99 \pm 8.11 \mathrm{~mm}^{2}$, while the largest area recorded was found in the group with CRP with $39.22 \pm 4.07 \mathrm{~mm}^{2}$. In 2014, Goncalvez et al. conducted a study where they evaluated the MM in subjects with removable complete and partial prostheses using kinesiography, and described the areas for each type of test food (peanut and Optocal) in the frontal and sagittal plane. In the case of the peanut, an average area in the frontal plane for the subjects with removable complete prostheses was reported as $58.5 \pm 32.5 \mathrm{~mm}^{2}$, while for the subjects with removable partial prostheses it was $160.6 \pm 52 \mathrm{~mm}^{2}$. For the sagittal plane, our results revealed an area for the group with CRP of $10.9 \pm 5.82$ $\mathrm{mm}^{2}$ and $9.94 \pm 0.56 \mathrm{~mm}^{2}$ for the group with CRP-P, while Goncalvez et al., reported areas of $12.5 \pm 2.5 \mathrm{~mm}^{2}$ and $17.5 \pm 7.5 \mathrm{~mm}^{2}$, respectively. The difference in the results of the two studies could be explained by the type of measuring instrument used, since the kinesiograph, due to its morphological characteristics, can cause alterations in the recordings and restrictions in the movement, inducing possible measurement errors. The EMA, on the other hand, has an accuracy of $0.3 \mathrm{~mm}$ described in the literature (Kaburagi et al., 2005) and specified by the manufacturer, and is considered to be a safe and noninvasive way to study human movements (Kuruvilla et al., 2007). Another factor that could affect this difference in the areas of the masticatory cycles is the design of the prosthesis and its condition.

When analyzing the opening speed and comparing it between the study groups (CRP, CRP-P and CRP-I), significant differences were shown between them, with the fastest average speed being for the group with CRP and the slowest for CRP-I, whereas in mandibular closing, there were only significant differences between CRP and CRP-I. This may be due to the group with CRP-P being the one with the greatest data dispersion, and since there is no specific classification of the edentulous areas of this group, it is not possible to establish that this variable distribution in speed is due to the tooth-prosthesis ratio. On the other hand, the average speed of the masticatory cycles for all the groups with prosthetic rehabilitation was greater in mandibular reduction, which agrees with Goncalvez et al., who, using peanut as the test food, assessed the opening and closing speed in subjects with removable complete and partial prostheses. The first group registered maximum speeds of $128.2 \pm 43 \mathrm{~mm} / \mathrm{s}$ and $92.8 \pm 26.7 \mathrm{~mm} / \mathrm{s}$ respectively and the subjects with the removable complete prosthesis was $157.4 \pm 35 \mathrm{~mm} / \mathrm{s}$ and $132.2 \pm 37.5 \mathrm{~mm} / \mathrm{s}$ respectively. These data are greater than those yielded in our study, and this difference in average speeds in the two studies can be explained, as with the results in the areas of the masticatory cycles, by the measuring instrument used, the type and condition of the prostheses. Wilding \& Shaikh (1997) complements this with their report that greater speed of mandibular acceleration during opening and closing is associated 
RIVERA, P.; FARFÁN, C.; ARIAS, A.; LEZCANO, M. F.; DIAS, F. J.; NAVARRO, P. \& FUENTES, R. Characteristics of mandibular movement and mastication in older adults with removable dental prostheses: Three-dimensional analysis. Int. J. Odontostomat., 14(1):81-88, 2020.

with a smaller particle size as well as the stabilization of the prosthesis (Wilding \& Shaikh; Karlsson \& Jemt 1991). A comparison of the opening and closing speed for each group found that there were only significant differences in the groups with CRP and CRP-P, and that the subjects with CRP registered the fastest speeds. These data do not agree with those reported by Jemt et al. (1983) who described subjects with complete prostheses as generally increasing the number of masticatory cycles and reducing the speed of the movements compared to the subjects with removable partial prostheses, who exhibit a faster mastication speed. This disparity in the two studies can be explained by the difference in test foods used, the measuring instrument and the study sample participants.

Subjects with dental prostheses, regardless of the type, they showed reduced ranges of motion (border and functional) compared to dentate subjects with no functional alterations whose values have been reported in the literature (Fuentes et al., 2017b). This difference decreases in subjects with CRP-I, who have values closer to those described for young dentate subjects, because this type of prosthesis improves sensory perception, offering greater comfort, stability and retention in those who wear them. According to our results, subjects with dental prostheses also have increased mastication frequency and speed, with smaller and faster masticatory cycles.

\section{ACKNOWLEDGEMENTS}

Ramón Fuentes and his research group have received support by the Research Office, Universidad de La Frontera. This work is part of the project DI160049 approved by the Universidad de La Frontera Scientific Ethics Committee (approval number 038/ 2016).

RIVERA, P.; FARFÁN, C.; ARIAS, A.; LEZCANO, M. F.; DIAS, F. J.; NAVARRO, P. \& FUENTES, R. Características de movimientos mandibulares y masticación en adultos mayores con prótesis dental removible: un análisis tridimensional. Int. J. Odontostomat., 14(1):81-88, 2020.

RESUMEN: El envejecimiento es un proceso dinámico que incluye varias alteraciones en la cavidad oral, siendo la pérdida de dientes la más frecuente. El tratamiento de rehabilitación puede incluir prótesis fijas o removibles y/o implantes. El objetivo de este estudio fue describir las características geométricas (trayectoria, rangos, áreas) y cinemáticas (velocidad) de los movimientos mandibulares y masticatorios en participantes con prótesis dentales realizando un análisis en tres dimensiones. Se consideró una muestra de 10 participantes con rehabilitación protésica y se dividió en tres grupos (prótesis total, atípica e implantosoportada), se midieron las características de los movimientos mandibulares bordeantes y masticatorios con articulografía electromagnética 3D. Se obtuvo el polígono Posselt en los planos frontal y sagital, se analizaron sus áreas, trayectorias y rangos. Se analizaron los movimientos masticatorios en cuanto al área de cada ciclo, la frecuencia, la velocidad y la razón entre el área el ciclo masticatorio y los movimientos bordeantes, sin diferencias significativas entre los grupos. Los sujetos con prótesis dentales, independientemente del tipo, mostraron disminución de movimiento (bordeante y funcional) en comparación con los sujetos dentados sin alteraciones funcionales cuyos valores se han informado en la literatura. Los sujetos con prótesis implantosoportada tienen valores más cercanos a lo que se describe para sujetos jóvenes dentados.

PALABRAS CLAVE: Movimientos mandibulares, articulografía electromagnética $3 \mathrm{D}$, prótesis dental removible, adultos mayores.

\section{REFERENCES}

Bourdiol, P. \& Mishellany, A. Tongue-mandible coupling movements during saliva swallowing. J. Oral Rehabil., 41:199-205, 2014.

Budtz-Jørgensen E. Prosthodontics for the Elderly. Diagnosis and Treatment. Chicago, Quintessence Publishing Co. Inc., 1999.

Díaz, S.; Arrieta, K. \& Ramos K. Impacto de la salud oral en la calidad de vida del adulto mayor. Rev. Clin. Med. Fam., 5(1):9-16, 2012.

Fuentes, R.; Dias, F.; Lezcano, M. F.; Álvarez, G.; Farfán, C.; Astete, N. \& Arias, A. Aplicación de la Articulografía Electromagnética en Odontología: análisis de la Masticación y Deglución. Int. J. Odontostomat., 12:105-12, 2018.

Fuentes, R.; Navarro, P.; Curiqueo, A. \& Ottone, N. E. Determination of mandibular border and functional movement protocols using an electromagnetic articulograph (EMA). Int. J. Clin. Exp. Med., 8:19905-16, 2015.

Fuentes, R.; Saravia, D.; Arias, A.; Lezcano, M. \& Dias, F. An innovative method to analyse the range of border mandibular movements using 3D electromagnetic articulography (AG501) and MATLAB. Biomed. Res., 28(9), 2017a.

Fuentes, R.; Arias, A.; Lezcano, M. F.; Saravia, D.; Kuramochi, G. \& Dias, F.J. Systematic Standardized and Individualized Assessment of Masticatory Cycles Using Electromagnetic 3D Articulography and Computer Scripts. Biomed. Res. Int., 3:1-9, 2017b.

Fulks, B.; Callaghan, K.; Tewksbury, C. \& Gerstner, G. Relationships between chewing rate, occlusion, cephalometric anatomy, muscle activity, and masticatory performance. Arch. Oral Biol., 83:16168, 2017.

Gartner, J. L.; Mushimoto, K.; Weber, H. P. \& Nishimura, I. Effect of osseointegrated implants on the coordination of masticatory muscles: a pilot study. J. Prosthet. Dent., 84(2):185-93, 2000.

Gonçalves, T. M. S. V.; Vilanova, L. S.; Goncalves, L. M. \& Rodrigues, Garcia, R. C. Effect of complete and partial removable dentures on chewing movements. J. Oral Rehabil., 41(3):177-83, 2014. 
RIVERA, P.; FARFÁN, C.; ARIAS, A.; LEZCANO, M. F.; DIAS, F. J.; NAVARRO, P. \& FUENTES, R. Characteristics of mandibular movement and mastication in older adults with removable dental prostheses: Three-dimensional analysis. Int. J. Odontostomat., 14(1):81-88, 2020.

Guyton, A. C. \& Hall, J. E. Tratado de Fisiología Médica. México, McGraw-Hill Interamericana, 1997.

Holm, B. \& Gotfredsen, K. Masticatory function and patient satisfaction with implant-supported mandibular overdentures: a prospective 5-year study. Int. J. Prosthodont., 15(6):575-81, 2002.

Jemt, T.; Hedegard, B. \& Wickberg, K. Chewing patterns before and after treatment with complete maxillary and bilateral distalextension mandibular removable partial dentures. J. Prosthet. Dent., 50:566-9, 1983a.

Jemt, T.; Hedegard, B. \& Wickberg, K. Chewing patterns before and after treatment with complete maxillary and bilateral distalextension mandibular removable partial dentures. J. Prosthet. Dent., 50:566-9, 1983b.

Kaburagi, T.; Wakamiya, K. \& Honda, M. Three-dimensional electromagnetic articulography: A measurement principle. $J$. Acoust. Soc. Am., 118:428-43, 2005.

Karlsson, S. \& Jemt, T. Adaptive changes of masticatory movement characteristics after rehabilitation with osseointegrated fixed prostheses in the edentulous jaw: a 10-year follow-up study. Int. J. Oral Maxillofac. Implants, 6:259-63, 1991.

Kodaira, Y.; Ishizaki, K. \& Sakurai, K. Effect of palate covering on bolus-propulsion time and its contributory factors. J. Oral Rehabil., 33:8-16, 2006

Kuruvilla, M.; Murdoch, B. \& Goozèe, J. Electromagnetic articulography assessment of articulatory function in adults with dysarthria following traumatic brain injury. Brain Inj., 21(6):60113, 2007.

Lauzardo, G.; Muguercia, D.; Gutiérrez, M.; Áreas, O. \& Quintana, M. La sobredentadura, una opción válida en Estomatología. Rev. Cuba Estomatol., 40(3), 2013.

Lepley, C. R.; Throckmorton, G. S.; Ceen, R. F. \& Buschang, P. H. Relative contributions of occlusion, maximum bite force, and chewing cycle kinematics to masticatory performance. Am. J. Orthod. Dentofacial Orthop., 139:606-13, 2011

Matus López, P. Salud Oral. En: D’Hyves C, Gutiérrez-Robledo, L. M. Geriatría. México, El Manual Moderno. pp. 335-47, 2006.

McKenna, G. \& Burke, F. M. Age-related oral changes. Dent. Update, 37(8):519-23, 2010.

McNeill, C. Temporomandibular Disorders. $2^{\text {nd }}$ ed. Chicago, American Academy of Orofacial Pain. Illinois, Quintessense, 1993.

N'Gom, P. I. \& Woda, A. Influence of impaired mastication on nutrition. J. Prosthet. Dent., 87:667-73, 2002.

Ohkubo, C.; Kobayashi, M.; Suzuki, Y. \& Hosoi, T. Effect of implant support on distal-extension removable partial dentures: in vivo assessment. Int. J. Oral Maxillofac. Implants, 23(6):1095-101, 2008.

Okeson, J. P. J. P.; Sosa, G. E. E. S.; Bumann, A.; Bumann, U. \& Lotzmann, U. Tratamiento de oclusión y afecciones temporomandibulares. 5 ed. Barcelona, Elsevier, 2008.

Posselt, U. Range of the movement of the mandible. J. Am. Dent. Assoc., 56:10-3, 1958.

Rosado De Oliveira, J. S.; Mattoso, F. C. P.; Costa De Oliveira, A.B. \& Dininno, C. Q. M .S. Fonoaudiologia e adaptação de prótese dentária total em idosos: o que os dentistas sabem sobre isto? Rev. Speech, Lang. Hear. Sci. Educ. J., 7(1):50-4, 2005.

Saez Carriera, R.; Carmona, M.; Jimenez Quintana, Z. \& Alfaro, X. Cambios bucales en el adulto mayor. Rev. Cuba Estomatol, 44(4):1-14, 2007.

San Martín, C.; Villanueva, J. \& Labraña G. Cambios del sistema estomatognático en el Paciente Adulto Mayor (Parte II). Rev. Dent. Chile, 93(2):96-101, 2002.

Slagter, A. P.; Bosman, F. \& Van der Bilt, A. Comminution of two artificial test foods by dentate and edentulous subjects. J. Oral Rehabil., 20:159-76, 1993.

Tallgren, A.; Mizutani, H. \& Tryde, G. A two-year kinesiographic study of mandibular movement patterns in denture wearers. J. Prosthet. Dent., 62:594-600, 1989.
Trulsson, M. Sensory-motor function of human periodontal mechanoreceptors. J. Oral Rehabil., 33:262-73, 2006.

Wilding, R. J. \& Shaikh, M. Jaw movement tremor as a predictor of chewing performance. J. Orofac. Pain, 11:101-14, 1997.

Woda, A.; Foster, K.; Mishellany, A. \& Peyron, M. A. Adaptation of healthy mastication to factors pertaining to the individual or to the food. Physiol. Behav., 89:28-35, 2006.

Yamashita, J. P.; Hatch, J. D. \& Rugh. Does chewing performance depend upon a specific masticatory pattern? J. Oral Rehabil., 26:547-53, 1999.

Yoshida E, Fueki K, Igarashi Y. Association between food mixing ability and mandibular movements during chewing of a wax cube. J. Oral Rehabil., 34(11):791-9, 2007.

Corresponding author:

Prof. Dr. Ramón Fuentes Fernández

Research Centre for Dental Sciences

Dental School, Universidad de La Frontera

Av. Francisco Salazar 1145

Temuco

CHILE

Email: ramon.fuentes@ufrontera.cl

Received: 04-03-2019

Accepted: 22-07-2019 